\title{
Aplikasi Informasi Akademik Berbasis Android
}

\author{
Jony \\ Jurusan Sistem Informasi STMIK MBC \\ Jl. Perintis Kemerdekaan No.62, Lawang Kidul, Ilir Tim. II, Kota Palembang \\ mbc.jony@gmail.com
}

\begin{abstract}
Abstrak - Smartphone merupakan sebuah alat yang di lengkapi dengan sistem operasi berupa Android, Android adalah sebuah mobile platform pertama yang lengkap dan gratis yang dikembangkan dengan menggunakan Software Development Kit (SDK) dengan tools yang cukup untuk mengembangkan aplikasi yang powerful dan kaya akan fitur. Dimana smartphone sudah banyak di gunakan di kalangan masyarakat dan perkembangan teknologi android yang begitu pesat sehingga juga berdampak langsung pada dunia pendidikan di Indonesia. Sekarang sudah banyak sekolah yang mulai memanfaatkan dunia teknologi informasi untuk meningkatkan pelayanan di bidang pendidikan. Banyak pengguna yang menggunakan android untuk membuat aplikasi informasi akademik yang bisa di jalankan di android sehingga menjadi layanan yang menarik. Aplikasi ini digunakan untuk berkomunikasi secara singkat pada siswa Sekolah Menengah yang terus meningkatkan pelayanan siswa baik secara akademis dan dalam fasilitas. informasi akademik berbasis android diharapkan dapat memberikan fasilitas yang lebih nyaman bagi siswa untuk mengetahaui nilai. Saat ini untuk melihat nilai dari materi pelajaran, siswa dituntut untuk datang ke sekolah. Untuk itu diharapkan aplikasi informasi akademik berbasis android ini dapat membantu siswa karena keterbatasan jarak dan waktu untuk dapat melihat nilai akademik siswa melalui media smartphone tanpa harus datang ke sekolah.
\end{abstract}

Kata Kunci- Android, Smartphone, Informasi Akademik, SMP Santa Theresia Pangkalpinang, teknologi informasi

\section{Pendahuluan}

Perkembangan Information Technology (IT) didunia semakin maju dan berkembang khususnya di Indonesia. Salah satu faktor yang mendukung perkembangan IT adalah hadirnya smartphone. Banyak hal yang dapat dilakukan melalui smartphone. Mulai dari chatting, bermain game, transaksi online, social media, membaca berita, dan menjelajah internet. Perkembangan tersebut tidak lepas dari perkembangan teknologi android yang begitu pesat sehingga juga berdampak langsung pada dunia pendidikan di Indonesia. Sekarang sudah banyak sekolah yang mulai memanfaatkan dunia IT untuk meningkatkan pelayanan di bidang pendidikan. Hal tersebut dapat dilihat dengan adanya website sekolah, sosial media sekolah, blog sekolah, hingga adanya internet yang membantu kebutuhan sekolah tersebut. Pemanfaatan bidang IT di sekolah tidak terbatas untuk guru, siswa, dan karyawan sekolah saja. Seharusnya orang tua juga bisa mendapatkan keuntungan dari pemanfaatan bidang IT tersebut dari sekolah, seperti penyampaian informasi mengenai nilai-nilai ujian. Dari penjelasan diatas maka penulis akan memfokuskan dalam pembuatan aplikasi penyampaian informasi. Aplikasi ini menggunakan media smartphone berbasis android dalam pengoperasiannya.

Penggunaan media smartphone dilakukan karena dapat digunakan dimana saja dan kapan saja sehingga memudahkan siswa untuk mengetahui informasi nilai-nilai ujian, biodata pribadi, biodata guru, jadwal pelajaran dan lain-lain. Selain itu android memudahkan programmer dalam pembuatan aplikasi karena android bersifat open source.

\section{Metode Penelitian}

Dalam upaya melengkapi data-data atau informasi dalam pengerjaan tugas perancangan sistem ini, maka penulis memperoleh data-data atau informasi yang dibutuhkan tersebut dengan beberapa metode, antara lain :

\section{A. Tahap Pengumpulan Data}

Pengumpulan data yaitu menggunakan metode-metode sebagai berikut:

\section{1) Metode Observasi}

Metode yang dilakukan penulis untuk mengumpulkan data dan mendapatkan hal-hal yang diperlukan untuk proses penelitian dengan cara mendatangi secara langsung ke Sekolah-sekolah.

\section{2) Metode Pustaka (Kepustakaan)}

Metode untuk mendapatkan data dengan cara mengumpulkan konsep-konsep atau teori dari buku-buku atau referensi lainnya yang dapat menunjang atau berkaitan dengan permasalahan yang dibahas dalam penyusunan laporan ini.

\section{3) Metode Wawancara}

Metode untuk mendapatkan data dengan cara berbincang-bincang atau menanyakan secara langsung pada sekolah-sekolah.

\section{B. Tahap Pembangunan Aplikasi}

Adapun tahapan pembangunan aplikasi adalah sebagai berikut:

\section{1) Analisis}

Pada tahapan analisis ini, proses yang dilakukan adalah dengan melakukan analisa masalah dan analisa proses sistem yang digambarkan dengan activity diagram, mendefinisikan kebutuhan fungsional, kebutuhan non 
fungsional, kebutuhan perangkat keras dan kebutuhan perangkat lunak yang selanjutnya digambarkan dalam bentuk Use Case Diagram.

\section{2) Perancangan}

Pada tahapan ini, proses yang dilakukan adalah merancang alur program dalam bentuk activity diagram. Dilanjutkan dengan membuat antarmuka user dengan menggunakan struktur navigasi dan rancangan layar.

\section{3) Implementasi dan Pengujian}

Tahapan ini mendeskripsikan cara penginstalan aplikasi dalam bentuk apk ke smartphone android, serta melakukan pengujian menggunakan teknik black box dan evaluasi aplikasi yang diuji langsung oleh pengguna kemudian pengguna dibagikan kuesioner sebagai bahan analisis penulis.

\section{PEMBAHASAN}

\section{A. Analisis Sistem}

Menurut Kristanto (2003) analisis sistem adalah suatu proses mengumpulkan dan menginterpretasikan kenyataankenyataan yang ada, mendiagnosa persoalan dan menggunakan keduanya untuk memperbaiki sistem. Menurut Yogiyanto (1995) analis sistem (analis informasi) adalah orang yang menganalis sistem (mempelajari masalah-masalahan yang timbul dan menentukan kebutuhan pemakai sistem) untuk mengidentifikasikan pemecahan permasalahan tersebut.

Sekolah merupakan sebuah lembaga pendidikan yang dituntut untuk dapat membekali siswa sehingga nantinya dapat menjadi generasi muda yang baik dan sesuai yang diharapkan. Hal ini dibutuhkan kerja sama dengan pihak sekolah dan juga peserta didik agar mencapai tujuan yang diinginkan. Terutama dalam pelayanan yang menyangkut akademik. Sejauh ini yang terjadi jika siswa ingin melihat hasil ujian, siswa harus datang ke sekolah dan bertanya kepada pihak yang bersangkutan. Hal itu menyebabkan kinerja bagian administratif dan guru yang bersangkutan menjadi tertumpuk dan tidak efisien dan informasi yang didapat oleh siswa tidak efektif karena harus mengantri dan menunggu lama untuk mendapatkan informasi tersebut.

\section{B. Analisa Sistem Berjalan}

Masalah yang sering terjadi pada sistem penyampain informasi tentang akademik yang ada di SMP Santa Theresia Pangkalpinang saat ini adalah keterbatasan waktu dan proses penyampaian informasi akademik yang dilakukan dengan cara yang manual, memberikan pengumuman mengenai informasi tentang nilai siswa yang di tempelkan di papan pengumuman, informasi pembayaran uang sekolah, informasi akademik lainnya. Untuk mengatasi masalah tersebut penulis akan membangun sebuah aplikasi layanan akademik untuk peserta didik di SMP Santa Theresia Pangkalpinang berbasis Android. Dari analisa yang telah dilakukan terhadap penyampaian informasi akademik konvensional di SMP Santa Theresia Pangkalpinang yang sedang berjalan saat ini, maka perancangan sistem ini dengan memanfaatkan teknologi aplikasi mobile yang dilakukan untuk dapat mengatasi berbagai masalah dan kendala yang ada pada sistem yang berjalan saat ini.

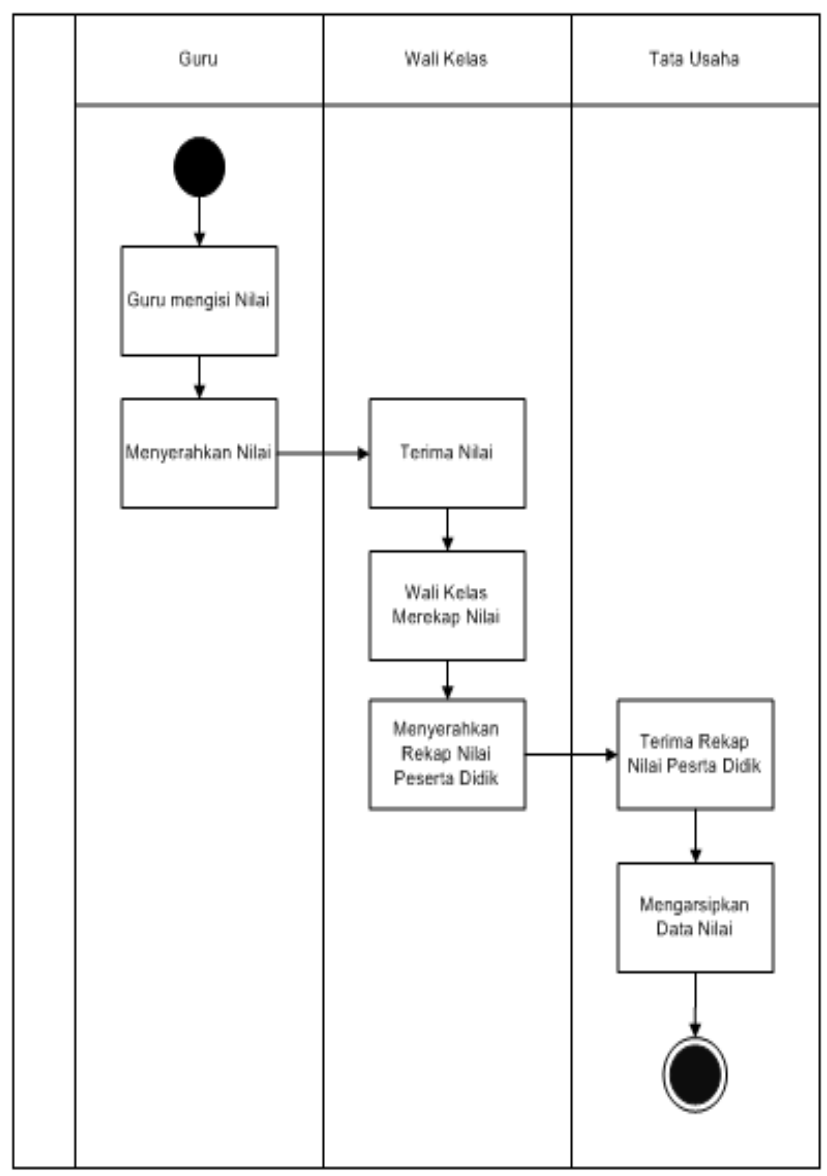

Gambar 1. Activity Diagram Nilai

\section{Perancangan}

Pada dasarnya usulan perancangan sistem yang dibuat banyak berubah dari sistem yang berjalan. Usulan sistem yang dirancang berubah pengolahan data yang selama ini dilakukan belum secara terkomputerisasi menjadi pengolahan data yang dilakukan dengan bantuan komputer dan smartphone. Perancangan ini akan memberikan gambaran mengenai aliran informasi dan proses yang sedang berjalan dalam sistem.

\section{1) Perancangan Aplikasi}

Tujuan dari perancangan aplikasi ini adalah untuk merancang sistem yang diusulkan setelah melewati proses analisis dan evaluasi permasalahan dari sistem yang sedang berjalan, sehingga sistem yang diusulkan dapat mengatasi berbagai masalah yang ada pada sistem yang sedang berjalan. Tahap ini sangat penting dalam menentukan baik atau tidaknya hasil perancangan sistem yang diperoleh.Some Common Mistakes 
a) Use Case Diagram

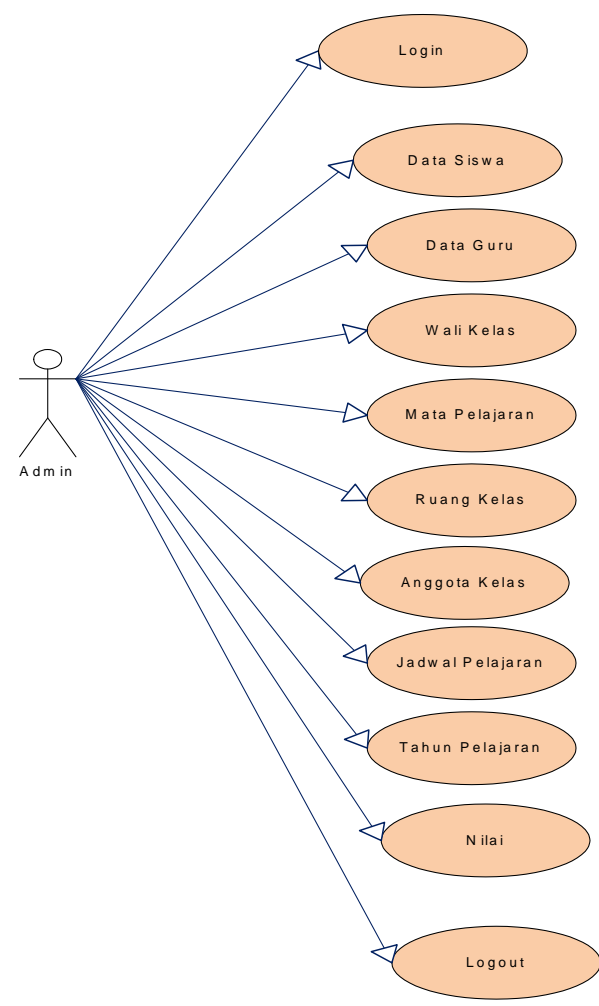

Gambar 2. Use Case Diagram Admin

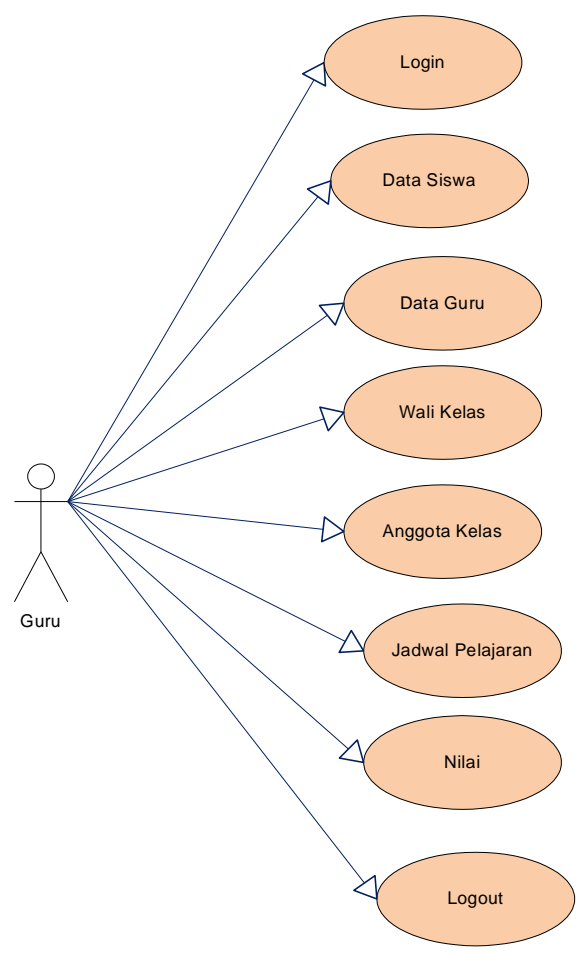

Gambar 3. Use Case Diagram Guru

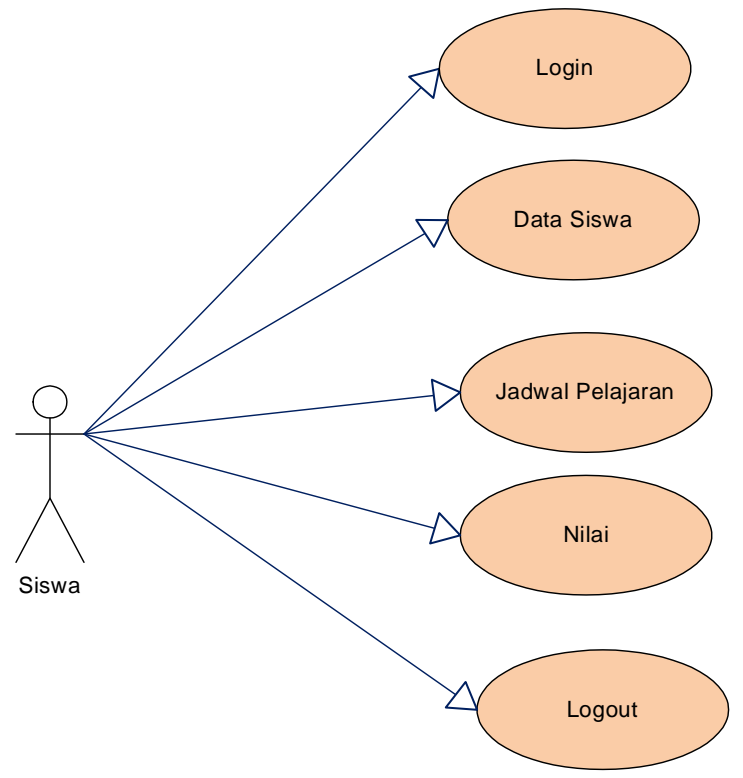

Gambar 4. Use Case Diagram Siswa

2) Perancangan Interface Aplikasi

a) Rancangan Layar Aplikasi

- Rancangan Layar Menu Utama Admin

\section{Admin}


- Rancangan Layar Menu Utama Guru

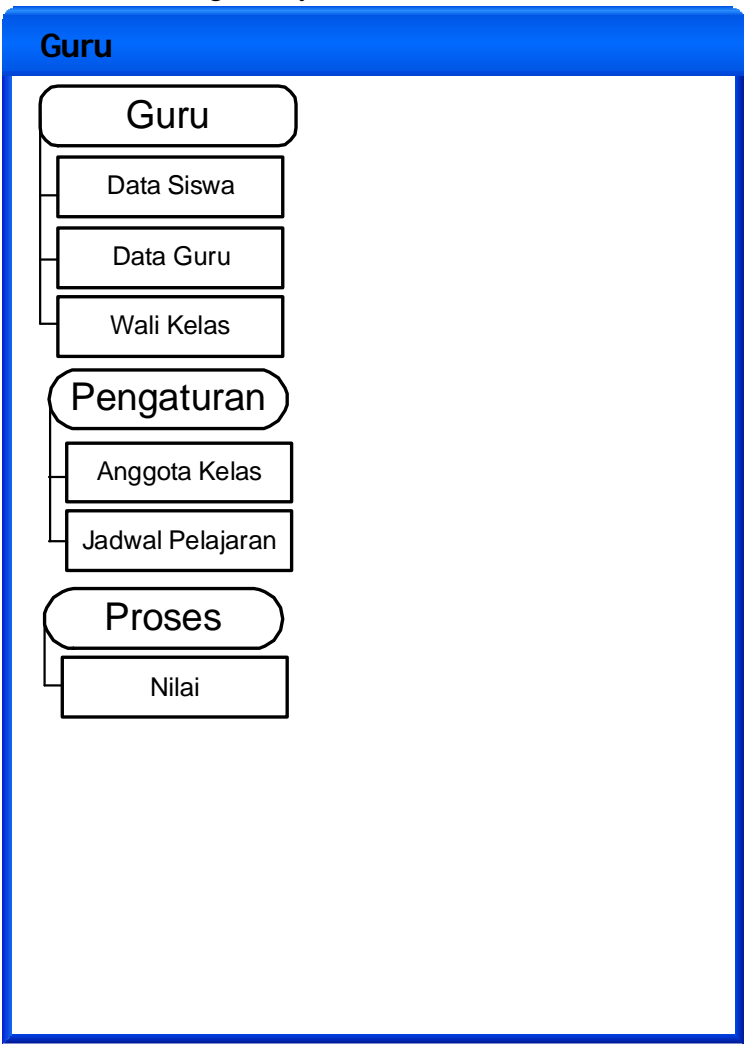

Gambar 6. Rancangan Layar Menu Utama Guru

- Rancangan Layar Menu Utama Siswa

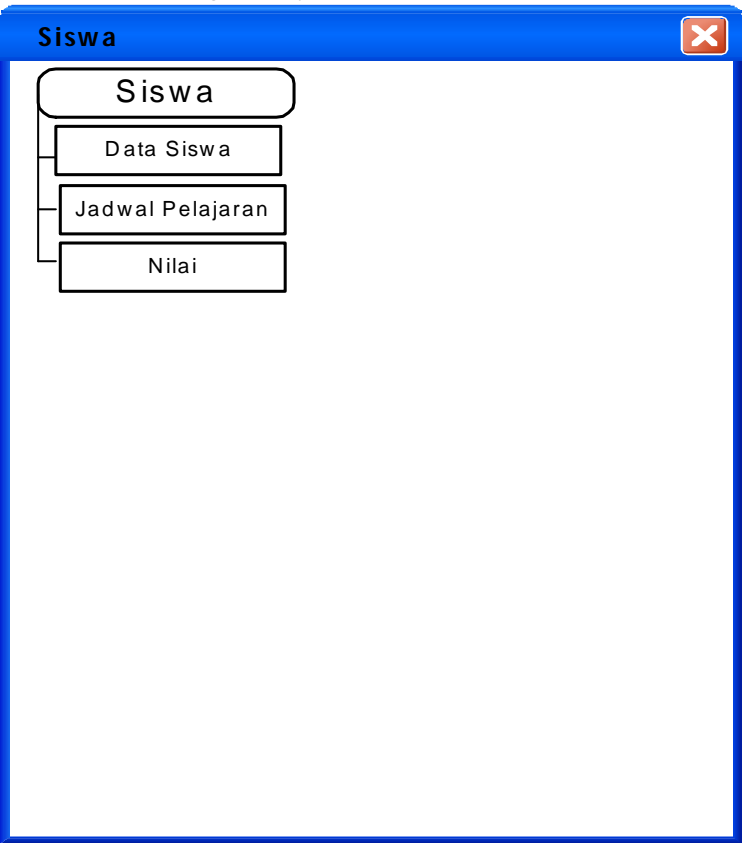

Gambar 7. Rancangan Layar Menu Utama Siswa
- Rancangan Layar Tambah Siswa

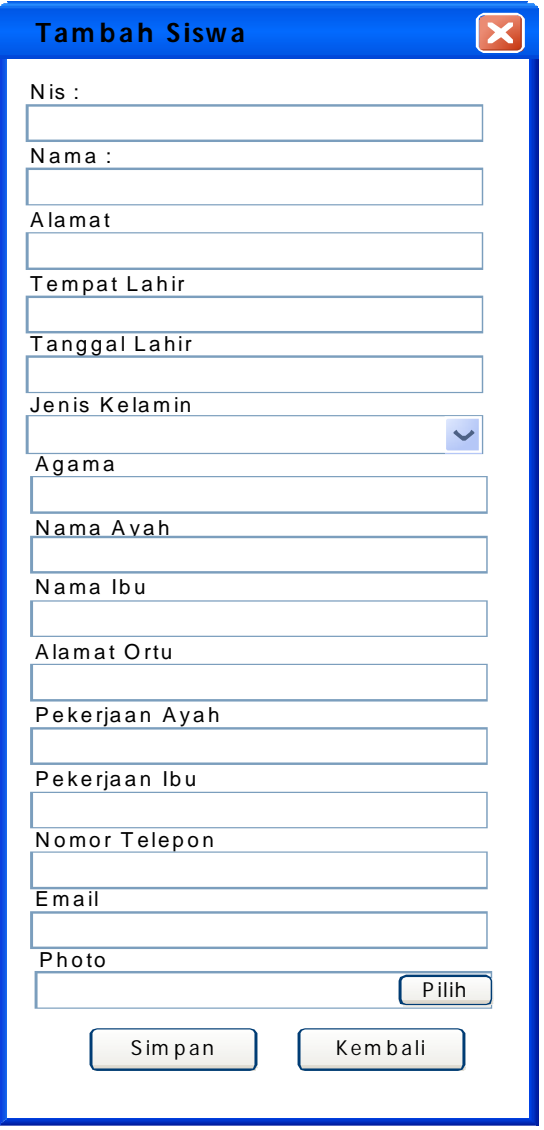

Gambar 8. Rancangan Layar Tambah Siswa

- Rancangan Layar Tambah Guru

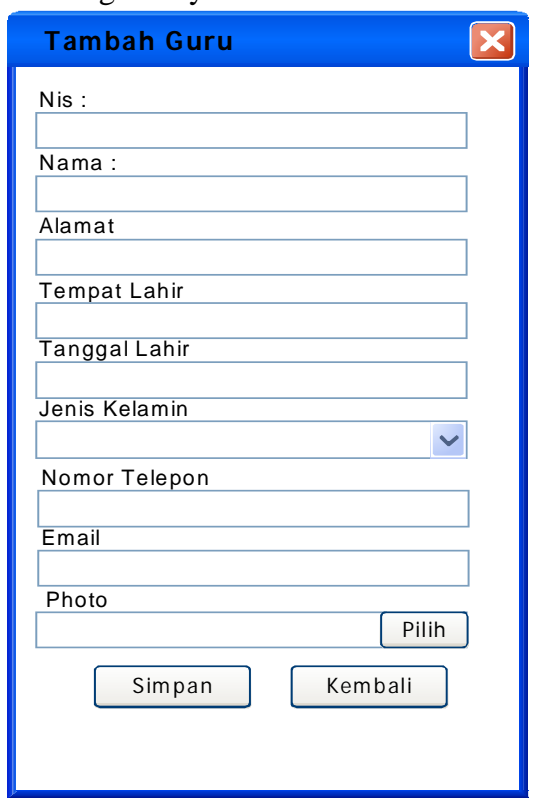

Gambar 9. Rancangan Layar Tambah Guru 
- Rancangan Layar Tambah Nilai

\begin{tabular}{l}
\hline Tam bah Nilai \\
\hline Kode Nilai \\
\hline Wali Kelas \\
\hline- -pilih-- \\
Siswa \\
\hline- -pilih-- \\
\hline Nama Kelas \\
\hline- pilih-- \\
\hline Mata Pelajaran \\
\hline- pilih-- \\
\hline Nilai Ulangan 1 \\
\hline Nilai Ulangan 2 \\
\hline Nilai Tuqas 1 \\
\hline Nilai Tugas 2 \\
\hline Nilai Harian \\
\hline Nilai UTS \\
\hline Nilai UAS \\
\hline Nilai Akhir \\
\hline Keterangan \\
\hline KKM Simpan \\
\hline Catatan Guru \\
\hline \\
\hline \\
\hline
\end{tabular}

Gambar 10. Rancangan Layar Tambah Nilai

\section{b) Tampilan Aplikasi}

- Tampilan Menu Login
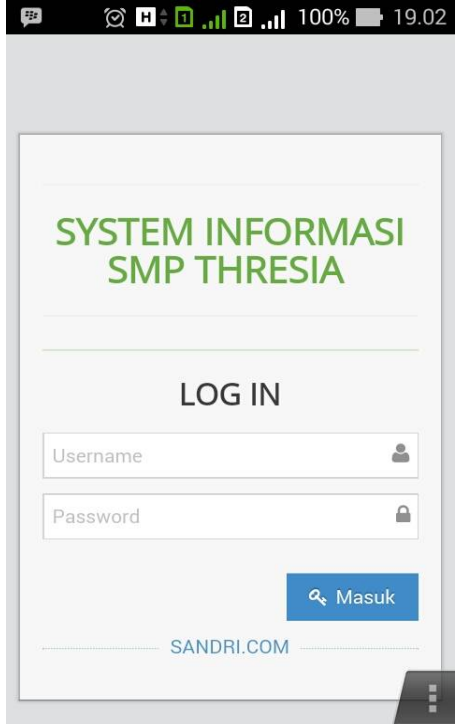

Gambar 11. Tampilan Menu Login
- Tampilan Menu Utama Admin

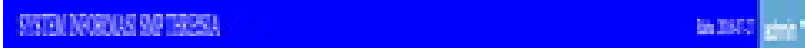

Dive dis:

을

1

Stanthent

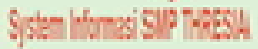

4.

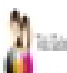

(i)

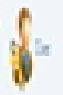

tixasy

1 ing

Gambar 12. Tampilan Menu Utama Admin

- Tampilan Menu Utama Guru

\section{mancting}

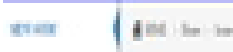

7axt

d

Shabibutio

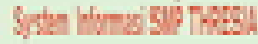

th

4
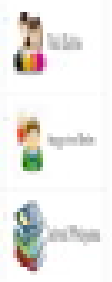

A.

Gambar 13. Tampilan Menu Utama Guru 
- Tampilan Menu Utama Siswa

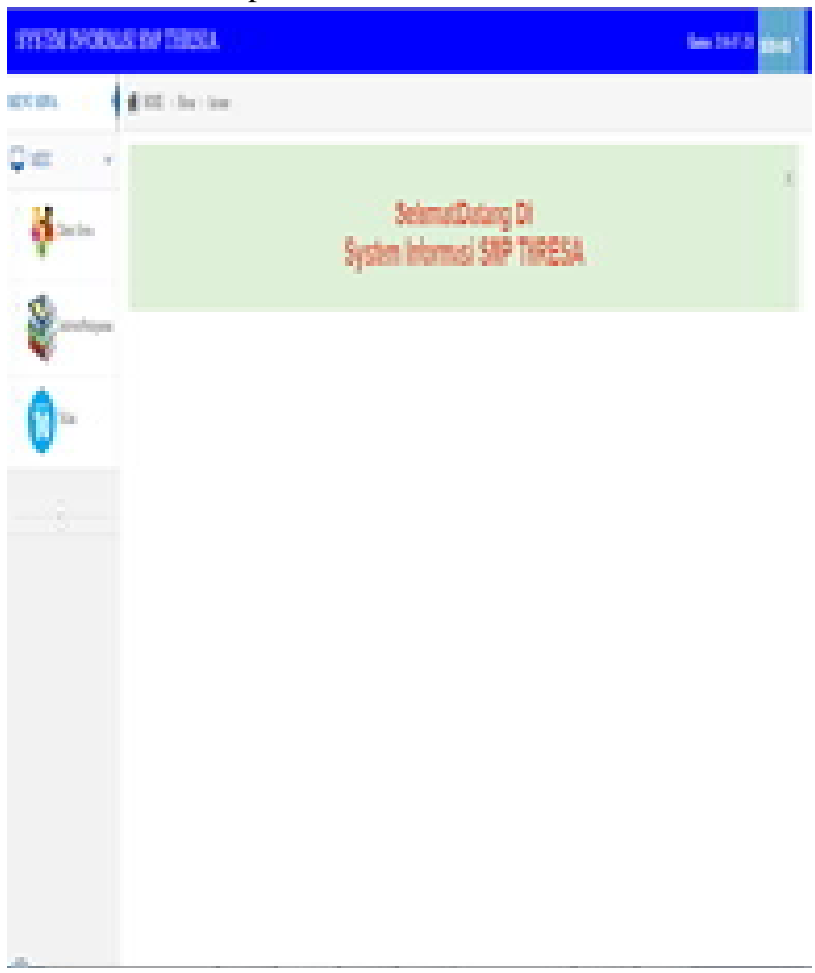

Gambar 14. Tampilan Menu Utama Siswa

- Tampilan Nilai

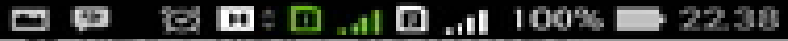

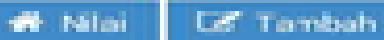

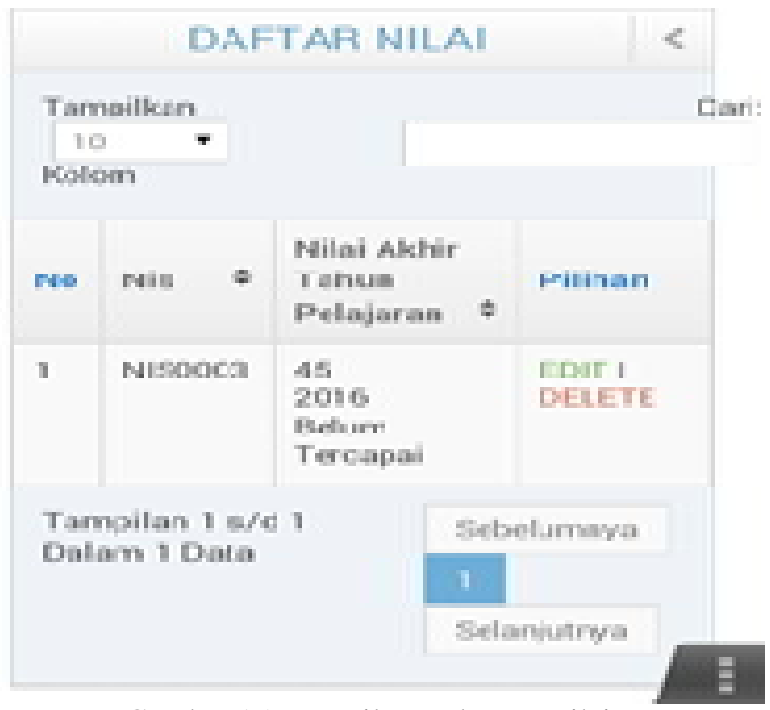

Gambar 15. Tampilan Halaman Nilai

D. Pengujian Sistem

1) Admin
Tabel 1. Pengujian Halaman Admin

\begin{tabular}{|c|c|c|c|}
\hline No & Katagori & Nama Tes & Hasil \\
\hline 1 & Akses User & $\begin{array}{l}\text { Tampilan Menu } \\
\text { utama }\end{array}$ & Ok \\
\hline 2 & $\begin{array}{l}\text { Sub menu } \\
\text { data siswa }\end{array}$ & $\begin{array}{l}\text { Daftar nama } \\
\text { siswa }\end{array}$ & Ok \\
\hline 3 & $\begin{array}{l}\text { Sub menu } \\
\text { data guru }\end{array}$ & $\begin{array}{l}\text { Daftar nama } \\
\text { guru }\end{array}$ & Ok \\
\hline 4 & $\begin{array}{l}\text { Sub menu } \\
\text { walikelas }\end{array}$ & $\begin{array}{l}\text { Daftar nama } \\
\text { walikelas }\end{array}$ & Ok \\
\hline 5 & $\begin{array}{l}\text { Sub menu } \\
\text { user }\end{array}$ & Daftar user & Ok \\
\hline 6 & $\begin{array}{l}\text { Sub menu } \\
\text { Mapel }\end{array}$ & $\begin{array}{ll}\text { Daftar mata } \\
\text { pelajaran }\end{array}$ & Ok \\
\hline 7 & $\begin{array}{l}\text { Sub menu } \\
\text { ruang kelas }\end{array}$ & $\begin{array}{l}\text { Daftar nama } \\
\text { kelas }\end{array}$ & Ok \\
\hline 8 & $\begin{array}{l}\text { Sub menu } \\
\text { anggota } \\
\text { kelas }\end{array}$ & Daftar isi kelas & Ok \\
\hline 9 & $\begin{array}{l}\text { Sub menu } \\
\text { jadwal } \\
\text { mapel }\end{array}$ & $\begin{array}{l}\text { Daftar jadwal } \\
\text { pelajaran }\end{array}$ & $\mathrm{Ok}$ \\
\hline 10 & $\begin{array}{l}\text { Sub menu } \\
\text { tapel }\end{array}$ & $\begin{array}{ll}\text { Daftar } & \text { tahun } \\
\text { pelajaran } & \\
\end{array}$ & Ok \\
\hline 11 & $\begin{array}{l}\text { Tambah } \\
\text { Data }\end{array}$ & Menambah data & Ok \\
\hline 12 & $\begin{array}{l}\text { Delete } \\
\text { Data }\end{array}$ & Menghapus data & Ok \\
\hline 13 & Edit Data & Mengubah data & $\mathrm{Ok}$ \\
\hline 14 & Detail & Detail data & $\mathrm{Ok}$ \\
\hline 15 & Logout & Keluar & $\mathrm{Ok}$ \\
\hline
\end{tabular}

2) Guru

Tabel 2. Pengujian Halaman Guru

\begin{tabular}{|l|l|l|c|}
\hline No & Katagori & Nama Tes & Hasil \\
\hline 1 & Akses User & $\begin{array}{l}\text { Tampilan Menu } \\
\text { utama }\end{array}$ & Ok \\
\hline 2 & $\begin{array}{l}\text { Sub Menu } \\
\text { Guru }\end{array}$ & $\begin{array}{l}\text { Melihat biodata } \\
\text { guru }\end{array}$ & Ok \\
\hline 3 & $\begin{array}{l}\text { Sub Menu } \\
\text { Siswa }\end{array}$ & $\begin{array}{l}\text { Melihat biodata } \\
\text { siswa }\end{array}$ & Ok \\
\hline 4 & $\begin{array}{l}\text { Sub Menu } \\
\text { Walikelas }\end{array}$ & $\begin{array}{l}\text { Melihat Nama } \\
\text { Wali kelas }\end{array}$ & Ok \\
\hline 5 & $\begin{array}{l}\text { Sub Menu } \\
\text { Angota Kelas }\end{array}$ & $\begin{array}{l}\text { Melihat Nama } \\
\text { Siswa dalam kelas }\end{array}$ & Ok \\
\hline 6 & $\begin{array}{l}\text { Sub Menu } \\
\text { Jadwal Mapel }\end{array}$ & $\begin{array}{l}\text { Melihat Jadwal } \\
\text { Pelajaran }\end{array}$ & Ok \\
\hline 7 & Input Nilai & Memasukan Nilai & Ok \\
\hline
\end{tabular}




\begin{tabular}{|l|l|l|c|}
\hline No & Katagori & Nama Tes & Hasil \\
\hline 8 & Detail & Melihat detail & Ok \\
\hline 9 & Logout & Keluar & Ok \\
\hline
\end{tabular}

\section{3) Siswa}

Tabel 3. Pengujian Halaman Siswa

\begin{tabular}{|l|l|l|c|}
\hline No & Katagori & Nama Tes & Hasil \\
\hline 1 & Akses User & $\begin{array}{l}\text { Tampilan } \\
\text { menu utama }\end{array}$ & Ok \\
\hline 3 & Sub Menu Siswa & $\begin{array}{l}\text { Melihat } \\
\text { biodata siswa }\end{array}$ & Ok \\
\hline 6 & $\begin{array}{l}\text { Sub Menu Jadwal } \\
\text { Mapel }\end{array}$ & $\begin{array}{l}\text { Melihat } \\
\text { jadwal } \\
\text { pelajaran }\end{array}$ & Ok \\
\hline 7 & Sub Menu Nilai & $\begin{array}{l}\text { Melihat nilai } \\
\text { Ok }\end{array}$ & Ok \\
\hline 8 & Detail Konten & $\begin{array}{l}\text { Melihat detail } \\
\text { konten }\end{array}$ & $\begin{array}{l}\text { Keluar dari } \\
\text { menu utama }\end{array}$ \\
\hline 9 & Logout & Ok \\
\hline
\end{tabular}

\section{PENUTUP}

\section{A. Kesimpulan}

Dari hasil analisa terhadap masalah dan aplikasi yang dikembangkan maka dapat ditarik beberapa kesimpulan, antara lain :

- Dengan adanya aplikasi ini, dapat memudahkan siswa dalam pengecekan nilai.

- Dengan adanya aplikasi ini siswa akan mengetahui jadwal pelajaran yang adakan di ajarkan hari ini dan seterusnya.

- Seorang administrator dibutuhkan untuk menjalankan aplikasi ini.

\section{B. Saran}

Berikut ini diuraikan juga saran yang mungkin bisa dijadikan pertimbangan dalam pengembangan sistem selanjutnya, antara lain:

- Spesifikasi perangkat keras harus sesuai dengan kebutuhan program sehingga aplikasi bekerja dengan benar.

- Diperlukan adanya perawatan dan pengawasan terhadap aplikasi ini.

- Penambahan fitur-fitur lain pada aplikasi.

- Informasi yang diakses melalui aplikasi ini masih terbatas.

\section{DAFTAR PUSTAKA}

[1] Alatas, Husein.(2013). Responsive Web Design dengan PHP \& Bootstrap. Yogyakarta:Lokomedia

[2] Arifianto, Teguh. (2011). Membuat Interface Aplikasi Android Lebih Keren dengan WUIT. Yogyakarta: Andi Publisher.

[3] Basuki, AP, 2010, Membangun Web Berbasis PHP dengan Framework Codeigniter, Lokomedia, Yogyakarta.

[4] Cinar, Onur. 2012. Android Apps with Eclipse. New York: Springer Science, Business Media.

[5] Darcey,L. dan Conder, S., 2010, "How to build an Android application, step by step", http://www.computerworld.com (akses tanggal 04 April 2016).

[6] Gargenta, M. 2011. Learning Android. O’Reilly Media: California.

[7] Kadir, Abdul, Form Zero tO A Pro Membuat aplikasi Web dengan HP dan Database MySQL, Penerbit Andi, Yogyakarta, 2009. Madcoms. Aplikasi Program PHP dan MySql,

[8] Nugroho, Adi. 2009. Rekayasa Perangkat Lunak Menggunakan UML dan JAVA. Yogyakarta : Penerbit Andi.

[9] Safaat H, Nazruddin, 2004. Pemrograman Aplikasi Mobile Smartphone dan Tablet PC Berbasis Android. Bandung: Penerbit Informatika

[10] Sugiri dan Budi K., 2007, Desain Web menggunakan HTML + CSS, Andi, Yogyakarta

[11] Sunyoto, Andi. 2007. Ajax Membangun Web dengan Teknologi Asynchronouse JavaScript \& XML, Yogyakarta: Penerbit Andi.

[12] Zaki, A dan Edy. W, Membuat Web Mobile dengan jQuery Mobile, PT. Elex Media Kompitindo, Jakarta, 2012. 